\title{
Microbodies in Methanol-grown Candida boidinii
}

\author{
By H. SAHM, R. ROGGENKAMP AND F. WAGNER \\ Lehrstuhl für Biochemie und Biotechnologie der Technischen Universität \\ Braunschweig, Gesellschaft für Molekularbiologische Forschung $\mathrm{mbH}$, \\ D-33 Braunschweig-Stöckheim, West Germany \\ AND W. HINKELMANN \\ Botanisches Institut der Technischen Universität Braunschweig, \\ D-33 Braunschweig, West Germany
}

(Received 4 December 1974)

\begin{abstract}
SUMMARY
Intracellular structures were observed in Candida boidinii grown in a medium containing methanol as the sole source of carbon and energy; these structures were absent in the same organism grown in the presence of glucose or ethanol. These substrate-specific structures are ultrastructurally similar to microbodies. Studies with sphaeroplast lysates and a mutant lacking alcohol-oxidase activity indicate that the alcohol oxidase may be located in these microbodies.
\end{abstract}

\section{INTRODUCTION}

As described in previous reports (Sahm \& Wagner, 1973a; Roggenkamp, Sahm \& Wagner, 1974), an FAD-dependent alcohol oxidase and a catalase are inducibly formed in Candida boidinii growing on methanol. In plant and animal cells flavin oxidase and catalase have been found to be at least partly located in microbodies (De Duve \& Baudhuin, I966; Tolbert, I97I). Furthermore, Kormendy \& Wayman (1974) observed the presence of substrate-specific structures in Candida utilis when this yeast was grown on $n$-butane or $n$-butanol. We describe microbodies in $C$. boidinii grown on methanol, and give some evidence that the alcohol oxidase is located within these particles.

\section{METHODS}

Preparation of extracts. Candida boidinii was cultivated in a basal medium as previously described (Sahm \& Wagner, I972). Cells were harvested in the late exponential growth phase, and extracts were prepared either by using an X-Press (Sahm \& Wagner, 1973a) or by the osmotic lysis of sphaeroplasts. Cells were converted to sphaeroplasts by treating with digestive enzymes from Helix pomatia as described by Kováč, Bednárová \& Greksák (1968). About $90 \%$ of the cells were converted to osmotically labile sphaeroplasts within 60 min at $30{ }^{\circ} \mathrm{C}$. The sphaeroplasts were lysed by lowering the mannitol concentration to $0.44 \mathrm{M}$ and by agitation with a Potter-Elvehjem homogenizer. Intact cells were removed from the crude sphaeroplast lysate and X-Press extract by low-speed centrifugation at $500 \mathrm{~g}$ for $10 \mathrm{~min}$. These extracts were subjected to further centrifugation at $5000 \mathrm{~g}$ for $30 \mathrm{~min}$ to sediment the particulate matter.

Enzyme assays. All spectrophotometric assays were performed on a Zeiss PMQII recording spectrophotometer at $30^{\circ} \mathrm{C}$. The following enzymes were assayed by published pro- 
cedures: alcohol oxidase (Sahm \& Wagner, I973a); catalase, EC. I . I I I .6 (Roggenkamp et al. 1974); formaldehyde dehydrogenase, EC. I.2.I.I and formate dehydrogenase, EC. I.2.1.2 (Sahm \& Wagner, I973b).

Protein determination. Protein was assayed by the Folin-Ciocalteu method as described by Lowry et al. (I95I). Standards were prepared with crystalline bovine serum albumin.

Electron microscopy. Cells were fixed in $3 \%(\mathrm{w} / \mathrm{v})$ glutaraldehyde in $50 \mathrm{~mm}$-phosphate buffer $\mathrm{pH} 6.9$, for 2 or $\mathrm{I} 6 \mathrm{~h}$. Following a thorough rinsing in the same buffer, cells were postfixed either in $2 \%(\mathrm{w} / \mathrm{v}) \mathrm{OsO}_{4}$ buffered with $50 \mathrm{~mm}$-phosphate $\mathrm{pH} 6.9$ for $2 \mathrm{~h}$, or in unbuffered $2 \%(\mathrm{w} / \mathrm{v}) \mathrm{KMnO}_{4}$ for $20 \mathrm{~min}$, and then washed and embedded in $2.5 \%(\mathrm{w} / \mathrm{v})$ agar. These agar blocks were dehydrated in a graded ethanol series, treated with propylene oxide, and embedded in Epon. Sections were cut with glass knives on an LKB Ultrotome, stained with lead citrate (Reynolds, 1963), and examined in a Philips EM 300 electron microscope.

\section{RESULTS AND DISCUSSION}

The electron micrographs in Fig. I show the typical structure of $C$. boidinii grown on methanol. Each cell contained a cluster of bodies varying in size from 0.4 to I $\mu \mathrm{m}$ in diameter; these bodies were surrounded by a single membrane and they may therefore be described as microbodies (Tolbert, I97I). Crystalloid inclusions were observed in these microbodies after postfixation in $\mathrm{OsO}_{4}$ (Fig. I $b$ ). The age of the yeast did not influence the presence of these microbodies. However, no sign of their presence was found in yeast grown on glucose or ethanol (Fig. 2) indicating that these structures may be associated with methanol metabolism.

This hypothesis is supported by the fact that about $80 \%$ of the alcohol-oxidase activity was found in particles which were collected from the sphaeroplast lysates by centrifugation for $30 \mathrm{~min}$ at $5000 \mathrm{~g}$ (Table I). A parallel study on cells broken by the X-Press showed that under these conditions only $20 \%$ of alcohol-oxidase activity was found in the sediment. These results indicate that the alcohol oxidase is particulate. While the last two enzymes of the dissimilatory methanol pathway, the formaldehyde dehydrogenase and the formate dehydrogenase (Sahm \& Wagner, I973b), are soluble enzymes, part of the catalase activity is also particulate (Table $I$ ).

Further evidence that the alcohol oxidase may be located in these microbodies is given by the mutant $4_{8}$ of $C$. boidinii, which is unable to grow on methanol because it lacks the alcohol oxidase (Sahm \& Wagner, 1973a; Roggenkamp et al. 1974). After growth on glucose, cells of this mutant incubated for $24 \mathrm{~h}$ in a methanol medium contained a cluster of microbodies, but in contrast to those in wild type, they lacked any crystalloid inclusions after postfixation in $\mathrm{OsO}_{4}$ (Fig. 3). This finding suggests that the inclusions in the microbodies represented crystals of the alcohol oxidase. The size of these crystals indicates that this enzyme must constitute a considerable proportion of the total protein in the microbodies, an observation consistent with biochemical results on the alcohol-oxidase content of C. boidinii (Sahm \& Wagner, 1973a).

The crystalloid inclusions described in this report resemble the crystalloid inclusions which have been observed in microbodies of Nicotiana tabacum (Frederick \& Newcomb, 1969) and in rat-liver cells (Baudhuin, Beaufay \& De Duve, 1965). However, the latter types were associated with catalase and urate oxidase, respectively. Since in $C$. boidinii the methanol seems to be oxidized by the alcohol oxidase as well as by the peroxidative action of catalase using the $\mathrm{H}_{2} \mathrm{O}_{2}$ which is generated by the alcohol-oxidase reaction (Roggenkamp et al. 1974), it may be that besides the alcohol oxidase, part of the catalase activity is located in 

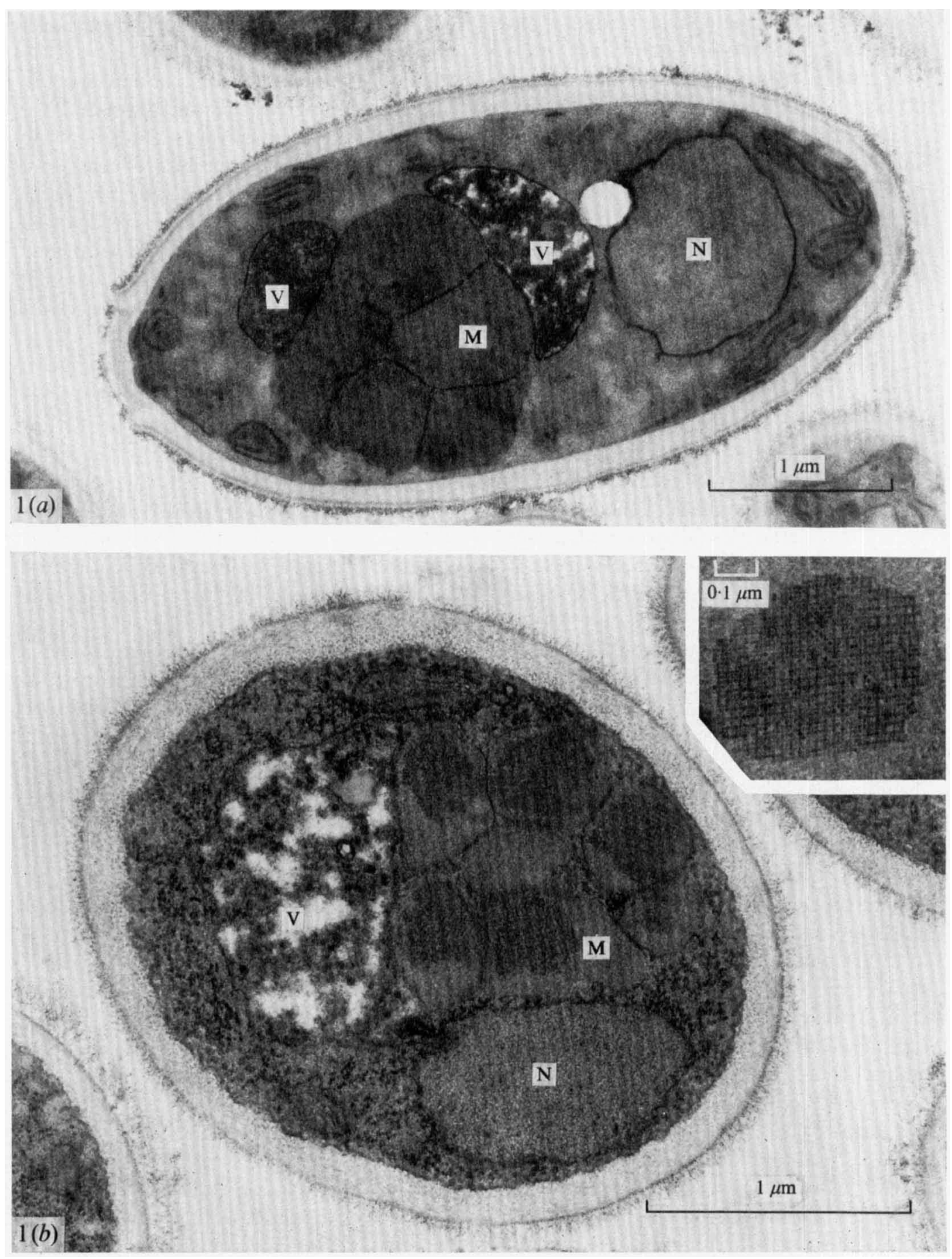

Fig. I. Candida boidinii grown on methanol $(a)$ postfixed in $\mathrm{KMnO}_{4},(b)$ postfixed in $\mathrm{OsO}_{4} . \mathrm{M}$, microbody; N, nucleus; V, vacuole. Inset: Higher magnification of a crystalloid core. 

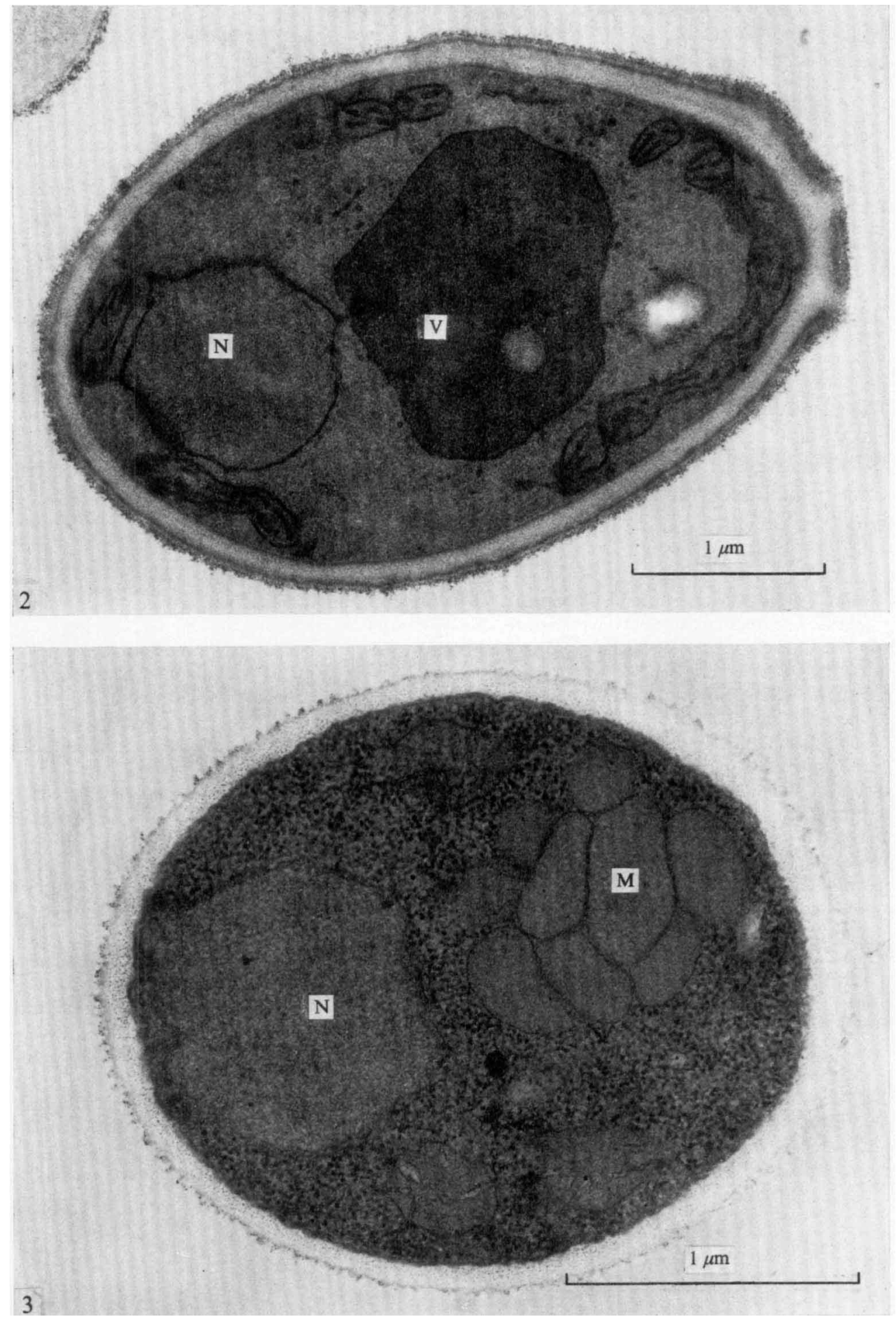

Fig. 2. Candida boidinii grown on ethanol, postfixed in $\mathrm{KMnO}_{4}$.

Fig. 3. Mutant $4_{8}$ of $C$. boidinii incubated for $24 \mathrm{~h}$ in a methanol medium, postfixed in $\mathrm{OsO}_{4}$. The microbodies (M) are without crystalloid cores. 
Table I. Distribution of alcohol oxidase, catalase, formaldehyde dehydrogenase and formate dehydrogenase between the supernatants and sediments of lysates and extracts after centrifugation at $5000 \mathrm{~g}$ for $30 \mathrm{~min}$

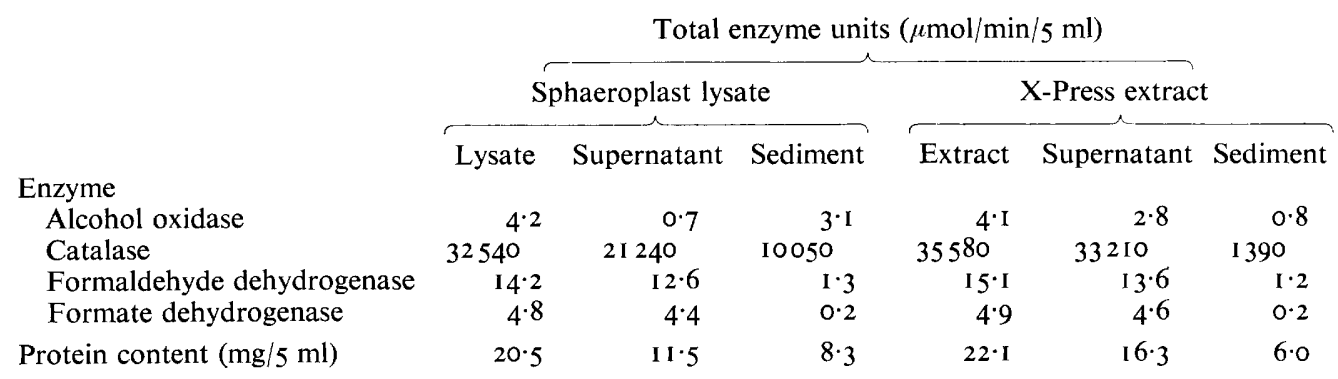

these microbodies. If this were so, the microbodies could be designated as peroxisomes (De Duve \& Baudhuin, I966).

We acknowledge the skilled assistance of Mrs M. Winde. This work was supported by grants from Bunderministerium für Forschung und Technologie and from VolkswagenStiftung.

\section{REFERENCES}

Baudhuin, P., Beaufay, H. \& De Duve, C. (1965). Combined biochemical and morphological study of particulate fractions from rat liver. Journal of Cell Biology 26, 219-243.

De Duve, C. \& Baudhuin, P. (I966). Peroxisomes (microbodies and related particles). Physiological Reviews $46,323-357$.

FREDERICK, S. E. \& NewCOMB, E. H. (1969). Cytochemical localisation of catalase in leaf microbodies (peroxisomes). Journal of Cell Biology 43, 343-353.

Kormendy, A. C. \& WAYMAN, M. (1974). Characteristic cytoplasmic structures in microorganisms utilizing $n$-butane and I-butanol. Canadian Journal of Microbiology 20, 225-230.

Kováč, L., BednÁrová, H. \& GreKsáK, M. (1968). Oxidative phosphorylation in yeast. I. Isolation and properties of phosphorylating mitochondria from stationary phase cells. Biochimica et biophysica acta I53, 32-42.

Lowry, O. H., Rosebrough, N. J., Farr, A. L. \& Randall, R. J. (I95I). Protein measurement with the Folin phenol reagent. Journal of Biological Chemistry 193, 265-275.

ReYNolds, E. S. (1963). The use of lead citrate at high $\mathrm{pH}$ as an electron-opaque stain in electron microscopy. Journal of Cell Biology 17, 108-212.

RoggenKamp, R., SAHM, H. \& WAGNer, F. (1974). Microbial assimilation of methanol. Induction and function of catalase in Candida boidinii. FEBS Letters 4I, 283-286.

SAHM, H. \& WAGNER, F. (1972). Mikrobielle Verwertung von Methanol. Isolierung und Characterisierung der Hefe Candida boidinii. Archiv für Mikrobiologie 84, 29-42.

SAHM, H. \& WAGNER, F. (1973 $a$ ). Microbial assimilation of methanol. The ethanol- and methanol-oxidizing enzymes of the yeast Candida boidinii. European Journal of Biochemistry 36, 250-256.

SAHM, H. \& WAGNER, F. (1973b). Mikrobielle Verwertung von Methanol. Eigenschaften der Formaldehyddehydrogenase und der Formiatdehydrogenase aus Candida boidinii. Archiv für Mikrobiologie 9o, $263-268$.

Tolbert, N. E. (1971). Microbodies - peroxisomes and glyoxisomes. Annual Review of Plant Physiology 22, 45-74. 